\title{
„Z kronik współczesnej mistyki” - Adam Zagajewski i Nowa Fala (opowieść postsekularna) ${ }^{1}$
}

\author{
"From the Chronicles of the Contemporary Mysticism": Adam Zagajewski and \\ the New Wave (a Postsecular Narrative)
}

\begin{abstract}
The subject of the present analysis are Adam Zagajewski's early works, written in the 1970s: the books of poems Komunikat, Sklepy mięsne and List, the novel Ciepto, zimno, the short story Boże Ciato, the critical literary texts, and finally, a little known essay W kilku punktach, published under the pen name Jan Garlicz. An attempt was made at the postsecular interpretation of these texts with particular emphasis on the analysis of the different from the author's later works attitude toward language and the Christian symbolism. In the offered rendition a significant topic and the irreducible context turns out to be the question of the possibility of non-religious, creative use of the Christian heritage by the secularized members of the Polish People's Republic society. In the final parts of the article Zagajewski's theses were extended to the works of the other members of the Generation '68, represented here primarily by the articles of S. Barańczak, and confronted with the Polish tradition of the studies on the relationship between literature and religion.
\end{abstract}

Keywords: Adam Zagajewski, Jan Garlicz, New Wave, Generation ‘68, postsecularism, sacrum, secularity

Streszczenie: Przedmiotem przedstawionych analiz jest wczesna, pochodząca z lat 70 . XX wieku twórczość Adama Zagajewskiego: wiersze z tomów Komunikat, Sklepy mięsne oraz List, powieść Ciepto, zimno, opowiadanie Boże Ciato, teksty krytycznoliterackie, a w końcu mało znany, opublikowany pod pseudonimem Jan Garlicz, esej W kilku punktach. Teksty te poddane zostały próbie interpretacji postsekularnej, w której szczególny nacisk położony został na analizę odmiennego niż w późniejszej twórczości Zagajewskiego stosunku do języka i symboliki chrześcijańskiej. W zaproponowanym odczytaniu istotnym tematem i nieredukowalnym kontekstem twórczości Zagajewskiego okazuje się pytanie o możliwość niereligijnego, twórczego wykorzystania chrześcijańskiego dziedzictwa przez zeświecczonych członków społeczeństwa PRL-u. W końcowych częściach artykułu jego tezy odniesione zostały

${ }^{1}$ Tekst powstał w ramach prac nad grantem „Literatura a religia - wyzwania epoki świeckiej" (NPRH 0052/NPRH4/2a/83/2016). 
do twórczości innych reprezentantów Pokolenia 68, reprezentowanych tu głównie przez artykuły Stanisława Barańczaka, i zestawione z polską tradycją badań relacji literatury i religii. Słowa kluczowe: Adam Zagajewski, Jan Garlicz, Nowa Fala, Pokolenie 68, postsekularyzm, sacrum, świeckość

Gdzie wzmaga się kryzys, mnożą się diagnozy:

Wielu młodych ludzi traci dziś wiarę bardzo wcześnie, bez głębszego namysłu i bez wielkiego cierpienia, takiego choćby, jakim przesycona była książka Parandowskiego Niebo w ptomieniach. (...) Piętnastolatek odrzuca wiarę skuszony iluzją łatwej nowoczesności i powszechnej racjonalności. Ogólny konformizm zwraca się przeciwko wierze. Trzeba wiele samodzielności a nawet męstwa, aby w miejskim środowisku przejść przez szkołę średnią i zachować wiarę. Nie tylko jednak te powierzchowne, socjologiczne motywy odsuwają od wiary, także kultura współczesna, literatura i filozofia, zwłaszcza zaś te jej nurty, które znajdują u nas wielu wyznawców (bo często wyznaje się kulturę, nie wiarę) pozbawione są pierwiastka duchowego, przeciwnie, są głęboko ateistyczne. (...)

Wszyscy nieomal w Polsce obchodzimy chrześcijańskie święta, choć tak wielu nie wie zbyt dobrze, jaka jest podstawowa intencja ich zachowania się, w jakim biorą udział święcie. Przypuszczam, że wielu z nas żyje w takiej mgle, wielu byłych katolików, obecnie ateistów, agnostyków, czy też ludzi, którzy w ogóle nie interesują się zdefiniowaniem swego stanu duchowego. Pytanie tylko, czy ta mgła powinna się rozrzedzić i w jaki sposób, czy ma opaść na ziemię, czy unieść się w górę. (...)

Katolicyzm polski został mocno zlaicyzowany, trochę przypomina te legendarne krzesła i stoły, zjedzone przez termity - zachowały jeszcze kształt, lecz najlżejsze dotknięcie obala je w proch. Pozornie tradycyjny i silny, jest polski katolicyzm w znacznej mierze fenomenem obyczajowym, aintelektualnym, oddalonym od tradycji kontemplacji, modlitwy, czy zwykłej rozmowy religijnej. Laicyzuje się - tak sądzę - inaczej niż na Zachodzie, mniej jawnie, lecz może przez to niebezpieczniej².

Choć przytoczony cytat nie należy do najkrótszych, to i tak składają się na niego jedynie fragmenty znacznie obszerniejszej diagnozy. Przerywając jej autorowi, odnotujmy, że przypomni on w niej jeszcze „śmierć Boga”, określi chrześcijaństwo jako niemodne i ostrzeże „zadowolonych” tradycjonalistów, niezdających „sobie chyba sprawy z podskórnej laicyzacji, z wyparowania wielkiej części treści religijnej”3. Całość nie może nie wydać się świetnie znana i służyć mogłaby wręcz jako podręcznikowy przykład użycia i przetworzeń uniwersalnych sekularnych toposów, tematów i metafor - częstych już w literaturze dziewiętnastowiecznej, zaś dla pisarzy, eseistów i publicystów wieku ubiegłego stanowiących już nieomal stały repertuar. Tylko w zacytowanych wyżej

\footnotetext{
2 J. Garlicz [A. Zagajewski], W kilku punktach, „Aneks” 1976, nr 12, s. 134-135, 137, 139.

3 Tamże, s. 139.
} 
fragmentach mamy wszak do czynienia z Marksowską metaforą zmiany stanu skupienia, Nietzscheańskim obrazem utraty orientacji po śmierci Boga (motyw poruszania się we mgle), dobrze znanymi obrazami pustki i wyjałowienia (w tekście pojawi się, rzecz jasna, Eliotowska Ziemia jatowa) oraz metaforą długotrwałej, lecz skrytej pracy termitów (znaczące, że uznanej przez diagnostę za „legendarną"). Nie zaskakują także analizy polskiej specyfiki, w których akcentuje się obyczajowo-kulturową motywację uczestnictwa w życiu religijnym i ostrzega uśpionych przed niebezpiecznymi konsekwencjami sekularyzacji „podskórnej”. Choć od przytoczonej diagnozy dzielą nas ponad cztery dekady, wydaje się, że znaczna część składających się na nią zdań spisana zostać mogła pięćdziesiąt czy nawet sto lat wcześniej; wielka narracja europejskiego sekularyzmu ma wszak korzenie w oświeceniu i wyraźnie rozbrzmiewała w dziewiętnastowiecznej Polsce. Równie dobrze jednak zdania te mogły wyjść spod piór badaczy i publicystów współczesnych. Pozostawiając już analizy socjologów, dyskutujących między innymi nad zjawiskiem „przynależności bez wiary” ${ }^{\prime}$, czy filozofów, próbujących uchwycić głębokie znaczenie i konsekwencje Taylorowskiej sekularyzacji5 , sięgnąć moglibyśmy tu chociażby do chętnie komentowanych, publicystycznych tekstów Andrzeja Draguły, ostrzegającego przed konsekwencjami dominacji polskiego „katolicyzmu kulturowego” i właściwej dlań „religijności naturalnej”" W nieco dłuższym eseju o „samosekularyzacji po polsku” przypomina on pochodzącą dokładnie sprzed 60 lat diagnozę młodego wówczas Josepha Ratzingera, ostrzegającego przed „nowym pogaństwem narastającym niepowstrzymanie w sercu Kościoła i grożącym mu drenażem od wewnątrz" by rozpoznania te potraktować jako „klucz do interpretacji aktualnej rzeczywistości Kościoła w Polsce”, w której - jak wynika z badań - „myślenie podług Ewangelii obce jest ponad połowie jej mieszkańców"8. Mając do dyspozycji najnowsze dane Instytutu Statystyki Kościoła Katolickiego, wskazuje przy tym Draguła na problemy bardzo podobne do tych, o których w 1976 roku wspominał Garlicz: od „braku osobistego odniesienia” do Boga wśród nominalnych katolików, przez nieobecność rzeczywistej „inicjacji” religijnej osób młodych, które „w sposób formalny i sakramentalny oczywiście w Kościele są, w dzieciństwie przyjęły przecież sakrament chrztu św., były katechizowane, przystąpiły do Pierwszej Komunii”, do spadku identyfikacji ze swą wspólnotą kościelną „zwłaszcza w środowiskach wielkomiejskich”. Nie próbuję powiedzieć tu,

${ }_{4}$ Zob. B. Mountford, Christian Atheist: Belonging Without Believing, Winchester 2011.

${ }^{5}$ Zob. Ch. Taylor, A Secular Age, Cambridge, MA, London 2007.

${ }^{6}$ Zob. A. Draguła, Kościót różnych prędkości, „Tygodnik Powszechny” 2018, nr 37, tenże, Co musi zrobić polski Kościót?, „Rzeczpospolita”, 5.09.2018, https://www.rp.pl/ Publicystyka/309059895-Co-musi-zrobic-polski-Kosciol.html, dostęp: 26.09.2018.

7 J. Ratzinger, Die neuen Heiden und die Kirche, „Hochland” 1958/1959, nr 51; cyt. za: A. Draguła, Polacy wierzacy poganie. Ratzinger czytany po 60 latach, „Więż” 2018, nr 1, s. 133.

${ }^{8}$ A. Draguła, Polacy wierzacy poganie..., dz. cyt., s. 134, 137.

9 Tamże, s. 136, 140-141. 
że kolejne analizy procesów sekularyzacyjnych wygrywane są na tę samą nutę, a jedynie tyle, że chociaż melodię tę dobrze znamy, to - niczym Ingrid Bergman w Casablance - mamy (być może równie głęboko skrywane) powody pragnąć, by odegrano ją dla nas jeszcze raz.

Jednocześnie wszakże w humanistyce i naukach społecznych ostatnich dekad wygłasza się sądy zgoła odmienne niż wyżej przywoływane: eksponujące religijne czy, jeśli wolimy, duchowe ożywienie, nawiązujące do bogatych tradycji obecności chrześcijaństwa w Polsce i Europie oraz podkreślające ich komplementarność, jeśli nie nadrzędność, wobec dyskursów szeroko rozumianego świeckiego racjonalizmu. Rzecz jasna i takie sądy wygłaszano wcześniej: czasem $\mathrm{z}$ intencją polemiczną, czasem $\mathrm{w}$ tonie agoniczno-triumfalistycznym, kiedy indziej - w trybie trzeźwej analizy i umiarkowanej prognozy. Czyni tak również autor $W$ kilku punktach, postrzegający wartości chrześcijańskie w społeczeństwie PRL-u jako „uśpione potencje, możliwości, które mogą być zrealizowane, lecz mogą też zostać przysypane, zagrzebane przez czas, okoliczności, sytuację" ${ }^{10}$. Wyrażając przekonanie, że „areligijność współczesnej kultury, jej znacznych połaci, to raczej słabość niż zdobycz”, pisze on o ,energiach duchowych tkwiących w postawie religijnej" i wskazuje na wykorzystywanie ich nawet przez zdeklarowanych ateistów: „Ilu partyjnych poetów pisze psalmy. Ilu partyjnych kompozytorów (...)"11. Rozpoznania takie cytować można długo; nie może dziwić, że jednym z najważniejszych zadań socjologii religii i historii idei ostatniego półwiecza stała się próba uzupełnienia o nie tak zwanej tezy sekularyzacyjnej. Wiadomo doskonale, że próby te cechują się dużą, nie tylko terminologiczną, różnorodnością; mowa wszak zarówno o tezy tej „uzupełnieniu”, jak i o jej „reinterpretacji”, „podaniu w wątpliwość” czy wręcz „odrzuceniu”. Kategoria postsekularności, znana przede wszystkim z głośnego wykładu Jürgena Habermasa z 2001 roku, w którym mówił on o współczesnych społeczeństwach zachodnich jako o „społeczeństwach postsekularnych" ${ }^{12}$, stanowi tylko jedno z imion otchłannego zadania przemyślenia bynajmniej nieoczywistych wzajemnych związków modernizacji i wierności chrześcijańskiemu dziedzictwu. $\mathrm{Z}$ pewnością nie jest ona imieniem pierwszym, nie jest też już dziś tym najmodniejszym zarówno dla socjologów, jak i dla filozofów i badaczy tekstów kultury, a wreszcie literaturoznawców. Wydaje mi się jednak, że akurat dla tych ostatnich, również w Polsce, stanowi ona propozycję szczególnie wartą uwagi - i to nie jedynie z tego powodu, że to literaturoznawca, John McClure, był jednym z pierwszych badaczy konsekwentnie stosujących to pojęcie ${ }^{13}$. Abym jednak mógł przedstawić powody poważniejsze, konieczna staje się symboliczna demaskacja

10 J. Garlicz, dz. cyt., s. 140.

11 Tamże, s. 135-136, 137.

12 Zob. J. Habermas, Wierzyć i wiedzieć, tłum. M. Łukasiewicz, „Znak” 2002, nr 9.

${ }_{13}$ Zob. na przykład J. Mc Clure, Pótwiary. Literatura postsekularna w czasach Pynchona i Morrison, tłum. T. Umerle, Kraków 2016. 
Jana Garlicza - wyjaśniająca jednakowoż, dlaczego spośród wszystkich diagnoz ze wszystkich pism na świecie, musiałem wybrać akurat jego.

\section{„Dwa serca”. W poszukiwaniu innego Zagajewskiego}

Rozpoczynając artykuł od spostrzeżeń Adama Zagajewskiego - bo to on ukrywał się pod pseudonimem Jan Garlicz - nie próbuję bynajmniej sugerować, że o wszystko, co chcielibyśmy wiedzieć o sekularyzacji, powinniśmy zapytać autora Komunikatu. Faktem pozostaje jednak, że esej W kilku punktach - powstały w 1976 roku jako odpowiedź na skierowane do autorów krajowych zaproszenie redakcji emigracyjnego pisma „Aneks” - stanowi wypowiedź przynajmniej z kilku względów interesująca, wybijającą się spośród lwiej części pozostałych tekstów cyklu Gtosy z kraju o chrześcijaństwie, socjalizmie, Kościele i polityce. Skoro - jak skrótowo ujmował jego zamysł Leszek Kołakowski - chodziło o refleksję na temat „spraw życia katolickiego i Kościoła w Polsce dzisiejszej”"14, nie może dziwić, że większość odpowiedzi koncentrowała się na stosunku opozycji demokratycznej do Kościoła katolickiego oraz politycznej roli i możliwościach tego ostatniego. Esej Zagajewskiego - z wykształcenia filozofa i psychologa, lecz zabierającego głos przede wszystkim jako pisarz - odróżniał się od nich już rozległością i założoną uniwersalnością przedstawionej diagnozy, obejmującej liczne nawiązania do teologii, kultury i literatury, od Dietricha Bonhoeffera, Paula Tillicha i Simone Weil, poprzez Franza Kafkę, Tomasza Manna i Wasilija Szukszyna do Jana Parandowskiego i Tadeusza Różewicza, a wreszcie „krakowskiego prymitywa Władysława Machejka"15. Wyraźnie wybrzmiewają w nim ponadto tony autobiograficzne. Poeta mówi o sobie jako o „agnostyku” i wyznaje: „nie jestem chrześcijaninem, nie wierzę", zaś o swoim dojrzewaniu opowiada w typowym dla społeczeństwa PRL-u sekularnym skrócie: „Zostałem ochrzczony, przyjąłem Pierwszą Komunię, spowiadałem się i modliłem, potem jednak, gdy miałem 15 czy 16 lat, straciłem wiarę" ${ }^{16}$. Niezależnie jednak od tego w jego eseju, przy akompaniamencie akuratnych deklaracji „szacunku” i „zrozumienia” dla chrześcijaństwa, pojawiają się wypowiedzi świadczące o stałym, pozainstytucjonalnym wpływie, jaki wywiera ono na trzydziestoletniego poetę. Już na wstępie zapowiada Zagajewski, że pisać będzie również o „tym, czego nie przeżył, nie umiał przeżyć, czego brak odczuwa”, a w zakreślonej przezeń perspektywie emancypacyjna narracja porzucenia religii nie może nie jawić się jako naznaczona melancholią opowieść o utracie: „Gdy, wiele lat temu, straciłem wiarę, czułem się naprzód jak wyzwoleniec. W miarę upływu lat i lepszej nieco orientacji w świecie kultury, a także w świecie społecznym i politycznym (a są one ściśle ze sobą zrośnięte) zacząłem dostrzegać,

\footnotetext{
${ }^{14}$ L. Kołakowski, Stowo wstępne, „Aneks” 1976, nr 12, s. 60.

15 J. Garlicz, dz. cyt., s. 140.

16 Tamże, s. 135-136.
} 
co straciłem" ${ }^{17}$. Tymczasowym punktem dojścia okaże się uznanie wagi problematyki metafizycznej („Uważam, że życie jest głębokie i tajemnicze, a także wielką i coraz większą wartość przywiązuję do postawy pełnej powagi”), której dalsza eksploracja już za jakiś czas pozwoli poecie opublikować takie książi, jak Solidarność i samotność czy Jechać do Lwowa. Równie ważny - jeśli nie ważniejszy - wydaje mi się wszakże fragment, w którym przyznaje on, że niezależnie od jego agnostycyzmu symbolika chrześcijańska zawsze pozostała dla niego „żywa”: „Ta symbolika, choć wiem o tym w sposób niejasny, ciagle trzyma mnie w swym zasięgu. Nie jest czymś obojętnym, historycznym” ${ }^{18}$. Pisząc o „trzymaniu” owym, nie może nie myśleć poeta o swej dotychczasowej twórczości; choć stosowane w niej chwyty nie zawsze przypominały Jakubowe zmagania z Aniołem, uznać należałoby, że uścisk transcendencji zostawić musiał w niej jakiś ślad...

Tym bardziej frapować może, że esej W kilku punktach pominięty został milczeniem przez wszystkich dotychczasowych monografistów poety (od Jarosława Klejnockiego i Tadeusza Nyczka, poprzez Annę Czabanowską-Wróbel do Bogusławy Bodzioch-Bryły) i, o ile mi wiadomo, nie został póki co uwzględniony w żadnej z analiz jego „metafizycznej” poezji. Wydaje mi się on tymczasem tekstem fundamentalnym, nie tyle nawet jako wypowiedź pozwalająca lepiej zrozumieć rozpoczynającą się wówczas dobrze już opisaną (zwłaszcza przez Czabanowską-Wróbel) przemianę postawy i poetyki Zagajewskiego, ile jako wiele mówiący autokomentarz do jego wcześniejszych i zdecydowanie rzadziej omawianych dziś utworów. We wskazanych w jego tekście „punktach” dopatrzeć można się na przykład nieomal kompletnego streszczenia opublikowanej rok wcześniej powieści Ciepto, zimno, w której konwencja Bildungs- i Künstlerroman służy zarazem autobiograficznemu wyznaniu (liczba odniesień do rzeczywistej biografii poety nie może nie zwracać uwagi), jak i zadaniu sportretowania społeczeństwa okresu małej stabilizacji; nieprzypadkowo chyba jej akcja kończy się w marcu 1968 roku gorzkimi intuicjami bohatera o nazwisku Lucjan Alpern („Czy nie spostrzegasz, jaka złość panuje w naszych domach? Złość w naszych domach”...), który porównany zostaje do "posługującego się archaicznym językiem, proroka”" ${ }^{19}$. Kończąca zacytowany fragment religijna aluzja nie należy bynajmniej do odosobnionych; można wręcz postawić tezę, że odpowiednio przetworzona symbolika religijna podtrzymuje głęboką konstrukcję powieści, którą da się czytać jako przejmującą opowieść o sekularyzacji. Tematykę tę zapowiada nie tylko znaczące „,rzymskokatolickie nazwisko” ${ }^{20}$ powieściowego alter ego poety, Krzysztofa Oremusa, ale i początek utworu, w którym przedstawiona zostaje matka bohatera:

\footnotetext{
17 Tamże, s. 134, 137-138.

18 Tamże, s. 136.

19 A. Zagajewski, Ciepto, zimno, Warszawa 1975, s. 232.

20 Tamże, s. 43.
} 
Matka wierząca. Miała duże, migdałowe oczy. Wzrostu średniego. Ubierała się w popielate płaszcze. Krzysztof tłumaczył znajomym, że wierzyła, ponieważ była taka piękna. Była przekonana, że to musi być jakoś użyte. Od czasu, gdy powoli zaczęła się starzeć, jej wiara rosła. Świątyniami tej wiary stały się kina. (...) Świetlistość ekranu kryła w sobie więcej tajemnic niż nabożeństwa w zimnych neogotyckich kościołach, ze starym księdzem przy ołtarzu. (...) Gdy bohaterowie filmu całowali się, zamykała oczy, jak w dzieciństwie w kościele, podczas Podniesienia. Nudziła się wszędzie poza kinem, przestała chodzić na spacery do parku i za miasto. - Prawdziwa natura - mówiła - ukazuje nam się w kinie. - Kiedyś powiedziała synowi, że miała widzenie. - Ukazał mi się Gerard Philippe. - Obok tego mechanicznie dotrzymywała wierności dawnemu wyznaniu, regularnie chodziła do spowiedzi. Obojętność matki wobec religii bolała Krzysztofa tym bardziej, że sam wierzył fanatycznie ${ }^{21}$.

Podobna „obojętność” stanie się cechą Krzysztofa z ostatnich stron powieści, wcześniej zaś jego dziecięca i młodzieńcza wiara poddana zostanie kolejnym próbom, w opisie których z upodobaniem mnożyć będzie Zagajewski religijno-świeckie paralele. Oto w trakcie jednej z lekcji nowy nauczyciel Krzysztofa „przerobi zagadnienie Boga”, z kaznodziejską pasją obwieszczając uczniom jego śmierć (w jego usta włożona zostanie obszerna parafraza 125. aforyzmu Wiedzy radosnej), szkolna zaś psycholożka zachęci go do wyznań słowami: „Możesz mówić śmiało, jestem kimś w rodzaju świeckiego księdza, jeśli nie przeszkadza ci to, że jestem także i kobietą. Jak na spowiedzi, tylko bez tych straszliwych emocji”, by na zakończenie konsultacji zwrócić się do niego sakramentalną formułą: „Ego te absolvo”22. Chociaż bohatera powieści już pod koniec szkoły średniej „opuściły wzruszenia religijne”, to jednak wciąż modli się on, tyle tylko, że - jak powiada - „w sposób świecki oczywiście”23. Socjologię studiować będzie „jak pobożny kleryk”, ukochana Wanda wyda mu się najpierw „neofitką”, następnie „kapłanką”, a w końcu „boginią”, lekarza, do którego uda się zaniepokojony po pierwszej spędzonej z nią nocy, nazwie „spowiednikiem”, koleżeńską grupę - „sektą”, zaś siebie samego po wystąpieniu z niej - „heretykiem”, któremu jej lider, „prorok” Lucjan, z pewnością „zadałby pokutę”24. Choć konstrukcja tego typu zestawień nie wydaje się odkrywcza, ich nagromadzenie i wyeksponowanie udanie współtworzą strukturę głęboką Ciepto, zimno, w której wyjściowe opozycje („Ja mam chyba dwa serca” - mówi Krzysztof matce po wspomnianej lekcji - „jedno z Bogiem i Sienkiewiczem, drugie z klasami uciskanymi i nieżywym Bogiem" ${ }^{25}$ ) zniesione zostaną w osobliwej dialektyce, której na imię - Literatura: „Dobrze się czuł w cudzych opowiadaniach.

\footnotetext{
${ }^{21}$ Tamże, s. 5.

22 Tamże, s. 20, 60, 65.

23 Tamże, s. 51, 61.

${ }^{24}$ Tamże, s. 94, 195, 222-223, 209.

25 Tamże, s. 21.
} 
Były to skrzydła, które przypinał sobie do ramion, i swobodnie wznosił się lub opadał"26. W charakterystyce tej usłyszeć można opublikowane już na początku lat osiemdziesiątych pamiętne wersy Zagajewskiego poety, na czele z programowym W cudzym pięknie o incipicie „Tylko w cudzym pięknie/ jest pocieszenie” i wymowną puentą Ody do wielości: „Wiersz rośnie na/ sprzeczności lecz jej nie zarasta"27. Wersy te odnosimy zwykle do późniejszych dokonań autora Jechać do Lwowa, jednak właśnie w głęboko ironicznej (i nie mniej autentycznej) twórczości z lat siedemdziesiątych zasadzie tej hołdował on w największym stopniu. Kontrapunktem dla powieści Ciepto, zimno wydaje się dla przykładu opublikowane w tym samym roku opowiadanie Boże Ciato, w którym znajdujący się w podobnym wieku i cechujący się podobną do Oremusa postawą pierwszoosobowy narrator - po długiej „dyskusji teologicznej”, inkrustowanej licznymi odniesieniami do chrześcijaństwa - w leżącym „,ciele najzwyklejszego śpiącego pijaka" dostrzeże tytułowe ciało Boga ${ }^{28}$. Kiedy jednak, pragnąc przenieść go w bezpieczne miejsce i udzielić mu pomocy, odpowie na wezwanie rzekomo opiekującego się pijakiem mężczyzny „Uklęknijmy”, zostanie przez niego (to ostatnie zdanie opowiadania) „uderzony w twarz, raz i drugi, potem w żołądek” tak, że „nic już nie pamięta, koniec”29. Choć fakt, że rzekomy „wysłannik” niebios okazał się kryminalistą, nie przekreśla wewnętrznej przemiany narratora, to z pewnością stawia ją na ostrzu ironii, nie pozwalając „zarosnąć przeżywanej przezeń sprzeczności: „Wierzyłem i nie wierzyłem jednocześnie. Te dwie myśli biegły obok siebie, różne, ale musiały zmieścić się w mojej głowie"30.

Zapomniane perypetie fikcyjnego Krzysztofa Oremusa odczytywać można również, śladem Nyczka ${ }^{31}$, jako autobiografizujące prolegomena do postępującej przemiany eseistyki Zagajewskiego. Podczas gdy Świat nie przedstawiony z 1974 roku kończył się spisaną jego piórem deklaracją, że zarysowany w tej książce „nowy świat kultury” i literatury „jest programem sztuki socjalistycznej”32, to w ostatnim szkicu opublikowanego cztery lata później w „Znaku” Drugiego oddechu za jedyny „ratunek” uznana zostanie „rzecz stara jak świat, mianowicie życie duchowe" ${ }^{33}$. Wskazując na potrzebę sztuki, w której nie zatraciłaby się „plazma intuicji metafizycznych”, dopowiada poeta, że „dzisiaj, u nas, życie

${ }^{26}$ Tamże, s. 208.

27 A. Zagajewski, List. Oda do wielości. Poezje, Paryż 1983, s. 34.

${ }_{28}$ Tenże, Boże Ciato, „Odra” 1975, nr 3, s. 66-67.

29 Tamże, s. 67.

30 Tamże, s. 66.

31 Zob. T. Nyczek, Dziesięć lat później [w:] tegoż, Kos. O Adamie Zagajewskim, Kraków 2002, s. 39-55.

32 A. Zagajewski, „Polska zdziecinniata”. „Życie utatwione”, nowy świat kultury [w:] J. Kornhauser, A. Zagajewski, Świat nie przedstawiony, Kraków 1974, s. 208.

33 A. Zagajewski, Drugi oddech [w:] tegoż, Drugi oddech, Kraków 1978, s. 143. Sformułowanie to uzna Czabanowska-Wróbel za „jeden z najwcześniejszych sygnałów zmiany” poetyki i światopoglądu poety, jeden z „momentów, który zadecydował o przełomie” (zob. A. Czabanowska-Wróbel, Poszukiwanie blasku. O poezji Adama Zagajewskiego, Kraków 2005, s. 36). 
duchowe wyładowuje się raczej za pośrednictwem eseju, poezji”, w związku z czym ta ostatnia powinna „wziąć siebie poważnie” - stawką jest wszak „regeneracja jakiejś intymnej substancji ludzkiego życia" ${ }^{34}$. Jeszcze w tym momencie wydawać się mogło, że „regeneracja” ta niekoniecznie prowadzić będzie musiała - jak w omówieniu Solidarności i samotności ujmie to Julian Kornhuaser - do „ekstatycznego hołdu złożonego wielobarwnemu życiu”, którego „opis (niepełny, poetycki) służy [poecie - dop. P.B.] rozpoznaniu samego siebie (w intymności, samotności atakowanej zewsząd „przez brzydkie bóstwo totalitaryzmu, echo historii, ciężar geografii)"35. Póki co wydaje się wszak Zagajewski poszukiwać możliwości artykulacji prawdy życia duchowego w „nieustannej walce $\mathrm{z}$ chaosem zjawisk, $\mathrm{w}$ polemice ze zdawałoby się nieprzejednanymi zjawiskami”36 (a zatem również z "trzymającą go w swoim zasięgu” chrześcijańską symbolika) - i taką też „walkę" tropi w tekstach omawianych w Drugim oddechu pisarzy. W Szumach, zlepach, ciagach wydaje się fascynować go nie tyle "trochę umowne, trochę spłowiałe” sacrum Mirona Białoszewskiego, co jego „frywolność, szczególna poufałość w stosunku do Biblii”, dezynwoltura, z jaką ,zakrada się do spichlerzy chrześcijańskich symboli, bo wyczuwa tam wciąż jedno wielkie bogactwo", w końcu zaś wolność w estetycznym eksplorowaniu „peryferiów duchowości” zgodnym z antagonizującą zasadą: „To, co czyste musi się zetknąć z nieczystym” ${ }^{37}$. Jednocześnie jednak wskazuje Zagajewski na ograniczenia „awangardowego estetyzmu”, skazujące poszukiwania Białoszewskiego na "stylizację" ${ }^{38}$. Podobne napięcie towarzyszyć będzie również jego omówieniu polemiki Jerzego Kronholda ze Stanisławem Barańczakiem, w którym raz jeszcze sformułuje zasadę prowadzonego wówczas przez siebie ,życia duchowego”:

To chyba oczywiste, że życie wewnętrzne nie odciąga od świata, tylko wzmacnia wobec świata; a karmi się wszystkim, co pożywne, skądkolwiek by się brało.

Spór o to, czy się zaostrzyć, czy też pozostać w sferze niejasnej, ma, przynajmniej dla mnie, jedno tylko rozstrzygnięcie: zaostrzyć się, widzieć dokładnie, mieć światopogląd. Gdyż ten kierunek duchowy wcale nie prowadzi do zerwania z życiodajną wielością ${ }^{39}$.

${ }^{34}$ A. Zagajewski, Drugi oddech, dz. cyt., s. 144.

35 J. Kornhauser, Życie wewnętrzne (Adam Zagajewski) [w:] tegoż, Międzyepoka. Szkice o poezji i krytyce, Kraków 1995, s. 146.

36 Tamże.

${ }^{37}$ A. Zagajewski, WWarszawie jak na wsi [w:] tegoż, Drugi oddech, dz. cyt., s. 103, 106, 101, 102.

38 Tamże, s. 107.

39 A. Zagajewski, Artysta bez wtaściwości [w:] tegoż, Drugi oddech, dz. cyt., s. 129. 


\section{„Skąpe światło”. Kiedy poezja nie znajduje blasku}

Jakie „życie wewnętrzne” manifestuje się w „zaostrzonych” i programowo światopoglądowych wczesnych wierszach Zagajewskiego ${ }^{40}$ ? Pragnąc odpowiedzieć jego własnymi słowami, wskazać należałoby na określony we wstępie Świata nie przedstawionego mianem "postawy duchowej” ${ }^{41}$ realizm, którego założenia nie powinny według poety przesłaniać „zdziwienia wobec świata, który zmienił skórę, niegasnącego zdziwienia, spokrewniającego literaturę z metafizyką" ${ }^{2}$. Za przynależną realizmowi „duchową technikę ujęcia świata” uznaje Zagajewski konkret, przy czym postulowana przezeń „literatura konkretu” miałaby nie tyle „obejść się bez symbolu” (z iluzoryczności takiego postulatu doskonale zdawał sobie poeta sprawę), ile „zetknąć się z ziemią”, wsłuchać się w czas („Chodzi tu do dobry słuch, o pewną muzykalność wobec historii”), a wreszcie podjąć zadanie „nieustannej konfrontacji symbolu z konkretem, ciągłego sprawdzania, czy obecne w świecie symbole nie martwieją, nie przeradzają się we własne przeciwieństwo, w przedmioty pozornego kultu”“33. Pochodząca z następnego zdania cytowanego tekstu, aprobatywnie użyta kategoria „idei wcielonej” ${ }^{44}$ wskazywać może na sposób, w jaki, kierując się poetyckim realizmem, ukonkretnia Zagajewski „trzymającą go w zasięgu” symbolikę chrześcijaństwa. Bez wątpienia okazał się on poetą historycznie „muzykalnym”, który szybko wysłyszał fałsz walki z chrześcijaństwem w imię idei postępu czego wymownym dowodem jest wymierzony w odgórną, partyjną sekularyzację Odczyt („Boga nie ma/ powiedział po raz drugi/ prelegent (...)/ boga nie $\mathrm{ma}$ / proszę o dyskusję", K, 36), a także stanowiące gorzką diagnozę jej skutków takie wiersze, jak Aniot Stróż (K, 46) czy Miasto, zawierające frazę: „Od dziesięciu lat oszukujesz swoją żonę/ w nocy waszym starym łóżkiem małżeńskim/ wypływacie na jezioro Genezaret” (K, 56). Ostatni z zacytowanych wersów stanowi reprezentatywny przykład najczęstszego w debiutanckim tomie sposobu wykorzystania symboliki religijnej i biblijnej - przetworzona, zaostrzona i ironiczna (jak ironiczny jest tytuł i koncept Komunikatu) wydaje się dostarczać języka pozwalającego krytycznie opisać społeczeństwo Polskiej Rzeczpospolitej

${ }^{40} \mathrm{Z}$ uwagi na liczbę cytatów i specyfikę wywodu w części tej stosować będę następujące skróty, odsyłające do zbiorów wierszy Zagajewskiego: K - A. Zagajewski, Komunikat, Kraków 1972; SM - A. Zagajewski, Sklepy mięsne, Kraków 1975; L - A. Zagajewski, List [w:] tegoż, List. Oda do wielości. Poezje, dz. cyt.; OdW - A. Zagajewski, Oda do wielości [w:] tegoż, List. Oda do wielości. Poezje, dz. cyt. Po przecinku podawać będę - bez zwyczajowego skrótu numer strony, z którego pochodzi zacytowany fragment.

${ }^{41}$ J. Kornhauser, A. Zagajewski, Wstęp [w:] tychże, Świat nie przedstawiony, dz. cyt., s. 5.

42 A. Zagajewski, Budowniczy Peiper [w:] J. Kornhauser, A. Zagajewski, Swiat nie przedstawiony, dz. cyt., s. 27.

43 A. Zagajewski, Walka konkretu z symbolem [w:] J. Kornhauser, A. Zagajewski, Świat nie przedstawiony, dz. cyt., s. 134, 135, 137.

${ }^{44}$ Tamże, s. 137-138. 
Ludowej. Dzieje się tak choćby w Egzekucji („Jest apostołem wyschniętego źródła/ Jego język drewniany uderza o policzki”, K, 23), w wygrywającym metaforę ślepoty Krecie („święty depozyt przez ostatnich świadków/ złożony w podziemnej arce Noego”, K, 24) czy w Prozie, której „nawiedzony” bohater „uwierzył/ i żeby przedłużyć drżenie obu dłoni/ ukrzyżował się” (K, 29).

Tu i ówdzie w Komunikacie motywy tego typu zapraszają wszakże do refleksji o odmiennym charakterze, zaś nieodłączna w ich podejmowaniu ironia i dystans okazują się służyć innemu panu: rozpalają oto nieomal teologiczne refleksje poety obcą tradycyjnej liryce religijnej żarliwością nowofalowego realizmu. Traktowane - jak o poezji mówić będzie Zagajewski późny - „z lekką przesadą" są one jednocześnie rozrzucane na tyle lekkomyślne, że wydają się wzniecać nowe, duchowe iskry. W wierszu Podróz - w warstwie powierzchniowej opowiadającym o muzyce Bacha - przerywającego na chwilę „emanację bytów” Boga opisuje poeta kolokwialnym ,a przecież to już nie jest/ młody człowiek", aby w drugiej strofie zaprosić czytelników do - wypełnionej słyszalnymi jeszcze echami mesjańskich obietnic - „doliny gdzie potęga oddechu/ z płuc wielkiego ssaka/ zmalała na tyle/ że mogli podjać przerwaną rozmowę" $(K, 13)$. Rozmowę taką (być może tę samą, na której potrzebę wskazuje Zagajewski eseista) podejmuje poeta także w Chorobie (K, 53), zgodnie z sekularną retoryką porównanej z „religią” i „nawróceniem”. Linię tę kontynuuje obraz „kościołów/ tych kościstych świątyń/ zachrypniętych od krzyku organów”, gdzie „prowadzi się hodowlę/ rosną suche gardła modlitwy”; jednak towarzyszący jej obraz „Boga tej religii”, który „jest zbyt nieśmiały/ zbiera znaczki pocztowe/ i ma swoich ulubionych bohaterów", wydaje się już jej kontrapunktem. Na uwagę zasługuje również tryptyk rozrzuconych po Komunikacie wierszy z niedzielą w tytule, zwieńczony efektowną Niedziela Palmowa (K, 52), w krótkich żołnierskich słowach opowiadającej alternatywną historię paschalną, w której Chrystus ukrzyżowany został „o tydzień za wcześnie, nie ogolony,/ w brudnym ubraniu, z wyrazem/ zaskoczenia na chudej twarzy”. W projektowanej tu implicite teologii, jaka odpowiedzieć mogłaby na tak niewczesne zdarzenie zbawcze, długotrwała pokuta, asceza, rekolekcje i „mistyczne wzloty” zastąpione zostają paramesjańską wizją , nowych świąt/ pełnych nieznanej radości pożarów”. Wieńcząca tryptyk i odwracająca plan wydarzeń Wielkiego Tygodnia Niedziela Palmowa aktualizuje retrospektywnie utajone teologiczne sensy poprzedzających ją „,niedzielnych” wierszy. Oto w rozmyślaniach „oficerów gwardii” z Niedzieli $w$ starym stylu zwracamy teraz uwagę na „dobrze wychowane grzechy”, „postną pamięć” i szable „zbawiające (...) ludzi od grzechu tłumu”, a wreszcie na wieńczący wiersz metaforyczny obraz „królewskich trzewi” uratowanych z „zamkniętych skorup” (K, 47). W końcu nawet w zupełnie świeckiej i niepozornej Niedzieli $(\mathrm{K}, 40)$ rozpoznawać zaczynamy nieostre kontury Niedzieli Zmartwychwstania: bohaterami przedstawionej w niej sceny są wszak „kobiety”, „żołnierze” i „młodzi urzędnicy”, którzy (dlaczego?) „piją wodę z basenu”, a w których dostrzec można zeświecczony powidok 
apostołów. Podobnie jak w relacji ewangelicznej ci ostatni przebywają razem, „żołnierze wychodzą”, a jedynie „kobiety przynoszą ze sobą/ swoje ciała”. Skoro relacjonowana w wierszu niedziela określona zostaje mianem „dnia, w którym nie dzieje się historia”, to być może dlatego, że Wszystko już się dokonało, a dziejowy chronos przesłonięty został mesjańskim kairosem?

Chociaż zarysowane tu, cokolwiek ryzykowne, odczytanie Niedzieli stanowić może jedynie nieostrą sugestię, a duchowy potencjał wielu wczesnych wierszy Zagajewskiego nigdy nie doczekał się interpretacyjnej aktualizacji, odwołań do symboliki chrześcijańskiej jest w jego pierwszych tomach na tyle dużo, że nie sposób pomijać ich milczeniem - zwłaszcza że występują one również w miejscach eksponowanych, jak w kończącej debiutancki tom Prawdzie, zawierającej pamiętną frazę ,jesteś Jonaszem który trawi wieloryba” (K, 58), czy w mającym otwierać go Komunikacie, w którym o dominującej w PRL-u postawie mówi poeta jako o „ironicznej religii wspomnień i podwójnej wiary” (L, 9). Nie inaczej jest w innych wierszach wydanego w 1978 roku w drugim obiegu Listu, do którego ostatecznie trafił Komunikat: w puencie Wiemy wszystko zapyta poeta ironicznie, „kto z nas wyrośnie/ katolicy czy chrześcijanie” (L, 19), matkom Zjadaczy chleba każe „nie wiedziećl w jakim języku modli się ich syn”, aby finalnie zwrócić się do nich modlitewną apostrofą „O/ Wy/ Anioły/ Zwykłości” (L, 16), zaś Miasto nieznane zakończy frazą: „A nam los w ręce włożył gwiazdę z Betlejem/ pełną krwi i ostruganą nożem” (L, 21). Liczne, specyficznie przetworzone odniesienia do chrześcijaństwa przykuwają jednak uwagę przede wszystkim w wydanych w 1975 roku Sklepach mięsnych, na których półkach odnaleźć można całkiem sporo poetyckich wiktuałów, nieznanych czytelnikom późniejszych tomów Zagajewskiego. Wzrok przykuwają zwłaszcza wiersze najwyraźniej mieszające z sobą symbolikę chrześcijańską i marksistowską, takie jak Śpiewnik zakończony litanijnym „niech cię strzėze/ niech cię broni/ Matka Boska Marksistowska” (SM, 27), Święto zawierające wymowną enumerację „odwrócone karty życia/ bezlitosne kurwy jedynego kościoła/ szulerów modlitwy i pierwszomajowych transparentów" (SM, 31), a wreszcie Baranek Boży który gtadzi grzechy świata, w którym w nieomal lingwistycznej manierze i tylko na pozór bluźnierczo przetwarza Zagajewski tytułowe liturgiczne wezwanie:

\footnotetext{
Baranek Boży który gładzi grzechy świata

Baranek Boże który pieści grzechy świata

cukrowy baranek z ziarnkiem soli zamiast oczu

od dawna zaprzyjaźnił się ze światem

Tylko umarły poeta $\mathrm{z}$ dziurawym językiem

nie może zrozumieć jak dobrze jest

żyć bez miłości w martwym morzu krwi (SM, 11).
}

Zacytowane fragmenty nie są w Sklepach mięsnych odosobnione, a na wciąż niezarośniętej sprzeczności chrześcijaństwa i marksizmu wyrastać wydaje się 
gros zamieszczonych $\mathrm{w}$ tomie wierszy: od tyleż erudycyjnego, co ironicznego Hegla o incipicie „Głosił że państwo jest/ marszem Boga w świecie/ Wobec tego miejsce porannej modlitwy/ zajmuje lektura dziennika" (SM, 42), poprzez bardziej osobistą Simone Weil (inc. „Nigdy nie spotkałem komunisty", SM, 16) i subtelnie introspektywne Doświadczenie wewnętrzne (SM, 10) do pozornie publicystycznych Filozofów (SM, 46), gdzie w polemice z „oszustwami” podkreślającymi wartość Pracy ukrywa poeta apostrofę „Boże kiedy wracam do domu/ chciałabym spać” (wyjąwszy inicjalne „Przestańcie” jedynie słowa „Bóg” i „Praca” zapisuje tu Zagajewski od wielkich liter). Jeszcze częściej „sprzeczność” religii i ideologii ożywia obecne w Sklepach... portrety zeświecczonych „urzędników” peerelowskiego społeczeństwa, którym co prawda jak ujmuje to poeta w wierszu o nader wymownym tytule $Z$ kronik wspótczesnej mistyki - „ukazuje się lew orzeł baranek i inne symbole”, jednak symboli tych „nie potrafią [oni - dop. P.B.] zrozumieć” (SM, 22). Paradoksy tej osobliwie postchrześcijańskiej kondycji wyzyskuje Zagajewski w Sklepach z konsekwencją i pasją, domagającymi się dokładniejszych analiz, w których bez wątpienia uwzględnić należałoby takie teksty, jak Czyściec („Czyściec jest chwilą łaski dla tych roślin/ które rosną w ciałach dziewic/ i aktem miłosierdzia dla prowincjonalnych mistyków/ którzy utracili wiarę”, SM, 19), Nowy świat („Książki których nie przeczytałem/ otwierają swoich siedem ran”, SM, 5), Potrawy bez smaku („od piętnastu lat mówi o potrawach bez smaku/ których przykładem jest hostia lub kawior/ pożywienie ludzi zamożnych i wierzących”, SM, 12) czy Koniec świata, w którym „Czterej jeźdźcy przemierzają ziemię/ w samochodach marki Nysa”, umożliwiając nam doświadczenie „chwili/ kiedy stare słowa nie są już ważne/ a nowych jeszcze nie ma”, kiedy „nadzieja nie ma na swoją obronę/ ani jednego słowa” i „kiedy nie ma nic/ ani wiary ani miłości” (SM, 26).

Wydaje się, że aby oddać sprawiedliwość wymienionym tekstom, należy spróbować usłyszeć je dziś w takiej właśnie chwili - w której na oczach poety dyskursy wyznaniowe i ideologiczne zaczęły rozpływać się w powietrzu, a jego twórczość, nie odnajdując jeszcze blasku metafizycznej pociechy, wpatrywać mogła się jedynie w „skąpe światło”, które „więcej chce ukryć niż ofiarować” (*** [Jak na cmentarzu], L, 17), zaś ledwo dostrzegalną w świecie „iskierkę nieskończoności” ocalać mogła „tylko wątpieniem/ niespokojnym przeczącym ruchem głowy/ zawieszonym w pytaniu głosem" (Tylko watpienie, L, 16). I ten bowiem moment (a może zwłaszcza on) zasługuje u Zagajewskiego na ocalenie oraz takie badawcze zainteresowanie, jakie próbowałoby wstrzymać się przed prześwietlaniem powstających wówczas frapujących poezji późniejszymi dokonaniami autora Niewidzialnej ręki. O ile bowiem często, jak obrazowo ujmuje to Czabanowska-Wróbel, próbowali badacze dostrzec „późnego” Zagajewskiego „ukrywającego się" w „młodym” ${ }^{45}$, o tyle kreślona tu perspektywa interpretacyjna pozwala rzucić światło na Zagajewskiego „młodego”, który nie zdążył się

${ }^{45}$ Zob. A. Czabanowska-Wróbel, Poszukiwanie blasku, dz. cyt., s. 23. 
jeszcze „zestarzeć”, a w którego wierszach załamuje się ono znacznie bardziej interesująco niż wówczas, gdy o poezji pisać będzie jako o „królewskiej drodze”. Twierdzi Klejnocki, że „»właściwy« Zagajewski to autor tekstów ostatnich (licząc od Jechać do Lwowa)”, stanowiących „centrum” jego twórczości, „a Komunikat i Sklepy mięsne to (...) elementy uwertury jedynie" ${ }^{46}$. Z opinią tą zgodzić mógłbym się wyłącznie, przypominając uwerturę do Snu nocy letniej Felixa Mendelssohna i zestawiając ją z napisanymi znacznie później na królewskie zlecenie Fryderyka Wilhelma kolejnymi trzynastoma częściami Snu, spośród których (nie tylko zdaniem Stanisława Haraschina) jedynie „świetne Scherzo dorównuje Uwerturze muzyczną wartością” - choć i tak „popularnością przewyższa ją niewątpliwie Marsz weselny, nieodłączny niemal atrybut uroczystości ślubnych” ${ }^{47}$. Kto czuje potrzebę, niechże wzrusza się przy późnych marszach bez końca. Ja pozostałbym przy uwerturze - $\mathrm{i}$ to dla niej nie oddam Zagajewskiego.

\section{„Nie całkiem” - chrześcijaństwo Nowej Fali}

Przygoda poezji Adama Zagajewskiego z lat siedemdziesiątych (opowiedziana tu z konieczności skrótowo i to w sposób, za którego dominantę uznać należałoby charakterystyczną dla jego późniejszej twórczości enumerację) ma również swój wymiar wspólnotowy, a najważniejsze cechy uchwyconego w niej stanu świadomości i prowadzonego „życia wewnętrznego” widoczne są również u innych najważniejszych przedstawicieli Pokolenia $68^{48}$. Wszyscy oni wszakże - jak trafnie rozpoznał to Tadeusz Nyczek - sukcesywnie poddawani byli „przymusowemu treningowi ateistycznemu”, a w dorosłe życie wchodzili „ze światopoglądem jeśli nie zdecydowanie lewicowym, to co najmniej laickim”, niejednokrotnie deklarując przy tym swój „agnostycyzm”; niektórzy z nich „należeli do PZPR i siłą rzeczy byli, choćby teoretycznie, marksistami”‘9. Kiedy zatem świeccy, krytyczni, nowocześni zwrócą się w swoich tekstach ku metafizyce i etyce chrześcijańskiej, te ostatnie przybiorą postać, jaką - z całą

46 J. Klejnocki, Bez utopii? Rzecz o poezji Adama Zagajewskiego, Wałbrzych 2002, s. 62-63. W ostatnim czasie opublikował Klejnocki zaczepny esej o antagonizującym tytule Dziesięć powodów, dla których inni polscy poeci nienawidza Adama Zagajewskiego, opowiadający o ,aksamitnym mordowaniu jednego z najwybitniejszych polskich poetów współczesnych" ([w:] I cień i światto... O twórczości Adama Zagajewskiego, red. A. Czabanowska-Wróbel, Kraków 2015, s. 88). Mam wrażenie, że tekst ten w znacznie większym stopniu przysłużyłby się Zagajewskiemu, gdyby jego autor wziął sobie do serca sposób, w jaki polemiki prowadził niegdyś na łamach „Studenta” sam poeta (zob. np. A. Zagajewski, Nie oddamy Kornhausera!, „Student” 1972, nr 19, s. 10).

47 T. Chylińska, S. Haraschin, B. Schäffer, Przewodnik koncertowy, Kraków 1973, s. 498.

${ }^{48}$ Pamiętając o ożywionych niegdyś dyskusjach terminologicznych i oddając sprawiedliwość stojącym za nimi racjom, w tekście niniejszym używam historycznoliterackich terminów Nowa Fala i Pokolenie 68 zamiennie.

49 T. Nyczek, Jakiś On [w: Określona epoka. Nowa Fala 1968-1993, wyb. T. Nyczek, Kraków 1995, s. 409. 
odpowiedzialnością, choć cudzym przecież słowem - określić można dziś mianem postsekularnej ${ }^{50}$. Podkreślał Nyczek, że u nowofalowych twórców

nawrót do tradycji chrześcijańskich (...) - z nielicznymi wyjątkami (L.A. Moczulski) - nie wiązał się z jawną konwersją, a co za tym idzie - na przykład z pojawieniem się w literaturze wątków religijnych. Polegało to przeważnie na wprowadzaniu do poezji najróżniej rozumianych motywów metafizycznych, a w pewnych przypadkach (wspomniani Barańczak, Zagajewski, też Krynicki) - bardziej zdecydowanych „wartości chrześcijańskich”. Nie wykraczało to jednak mimo wszystko poza granice „wizyjnego sceptycyzmu” bądź „metafizycznego wątpienia” ${ }^{\text {.1 }}$.

Rówieśnik i przyjaciel poetów Nowej Fali podkreśli zróżnicowanie poetyckich projektów wielu z nich - wymieniając między innymi „swoisty panteizm” Kronholda czy „ekumenizm” Krynickiego ${ }^{52}$ - i pod tym kątem skompletuje w swej antologii zestaw wierszy, które w najciekawszy, jego zdaniem, sposób podejmowały tematykę „metafizyczną”. I chociaż można dyskutować z Nyczkiem antologistą, proponując wybór innych tekstów, a nawet autorów (nie może nie zastanawiać na przykład, dlaczego nie sięgnął on do żadnego tekstu Kornhausera, w interesujący sposób łączącego diagnozę zeświecczenia z autorskim przetworzeniem wątków judaistycznych), generalna diagnoza Nyczka historyka pozostaje w cenie - wydaje się tylko, że należałoby ją dziś ostrożnie doprecyzować. Oto pochodząca z końca lat sześćdziesiątych i z lat siedemdziesiątych twórczość zeświecczonych młodych poetów Pokolenia 68 - przetwarzająca dostępną im tradycję religijną (język, symbolikę i obrazowanie judeochrześcijańskie, biblijne, liturgiczne) w sposób, którego dominantę stanowiła głęboka nieufność do języków władzy, dyskursów ideologicznych czy, jeśli kto woli, wszelkich wielkich narracji - okazała się twórczością par excellence postsekularną, to jest twórczością wypracowującą i powołującą do życia nowe formy artykulacji i przeżywania „życia duchowego”. Poeci Nowej Fali dokonywali tego różnymi sposobami, za pomocą odmiennych poetyk, strategii i środków artystycznych, dialogując z wieloma partnerami i wczytując się w teksty innych mistrzów. Podczas gdy dla Barańczaka będą nimi przede wszystkim Miron Białoszewski, Tymoteusz Karpowicz i Witold Wirpsza, w związku z czym uprawianą przezeń twórczość traktować można jako kontynuację ich teolingwistycznych poszukiwań, Zagajewski w artykule dla „Aneksu” wskazywać będzie akurat na Franza Kafkę, którego nazwie

50 Zob. na przykład P. Bogalecki, Szcześliwe winy teolingwizmu. Polska poezja po roku 1968 w perspektywie postsekularnej, Kraków 2016.

51 T. Nyczek, Jakiś On, dz. cyt., s. 410.

52 Tamże. 
„wielkim patronem dwudziestowiecznej literatury”, przypominając, że Tomasz Mann celnie określił go mianem "religijnego humorysty”"53.

Niezależnie jednak od oczywistych (i chwalebnych!) różnic, wspólny wydaje się dla poetów Nowej Fali stan wyjściowy, za którego celną, choć spisywaną na gorąco, charakterystykę posłużyć mógłby tu opublikowany w 1972 roku w "Studencie” artykuł Barańczaka „Powiedz prawdę, do tego stużysz”. Na tytuł nie przez przypadek wybrany został cytat z Zagajewskiego, gdyż esej ten stanowi zbiorcze omówienie jego Komunikatu, Samopalenia Kronholda oraz tomu Drozd $i$ inne wiersze Krzysztofa Karaska. Wybierając z nich trzy utwory (kolejno: Odczyt, Farsz i Drozda), w których - za każdym razem „w innym anegdotycznym i poetyckim przebraniu" - pojawia się Nietzscheańskie Gott ist tot, wskazuje Barańczak na pierwszą cechę analizowanej twórczości: oto „w świecie tych trzech poezji nie ma - przynajmniej na etapie wstępnej diagnozy - żadnej transcendencji, żadnego autorytetu, na którym można by się spokojnie i pewnie oprzeć” ${ }^{4}$. Brak ów nie może nie pociągać za sobą - oto i cecha druga - postępującego „kryzysu zaufania”: „Wszystko jest podejrzane, we wszystkim kryje się potencjał fałszu. Nawet w tym, co powinno nas łączyć a nie dzielić, co powinno być domeną zaufania i porozumienia” (wymowne, że poeta wskazuje tu na „miłość” i „przykazania dekalogu”" ${ }^{2}$ ). Najistotniejsza wydaje się jednak poecie właściwość trzecia: oto „bardzo znamienną” cechą omawianych poetów - „bardzo przecież dalekich od lingwistycznych praktyk” - okazuje się „skojarzenie owego

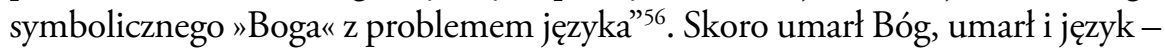
a jeśli tak, to i metafizyki nie sposób już opiewać, bezkrytycznie czerpiąc z odziedziczonych religijnych dykcji. Oznacza to jednak, że przed poszukującą prawdy poezją rozwiera się nowe, otchłanne zadanie - martwym językiem nauczyć się posługiwać tak, by w jakiś sposób wskrzesić życie duchowe w świecie, którego Bóg jest Bogiem umarłym. Poezji przypisana jest tu rola niepomiernie większa niż w tradycyjnej liryce religijnej - a niniejsza opowieść o mniej lub bardziej zapomnianych wierszach z lat siedemdziesiątych okazuje się dziś zadziwiająco aktualna i to bynajmniej nie wyłącznie z powodu jej zaangażowania politycznego. Choć od 1968 roku mija pół wieku, wsłuchujemy się dziś w innych „nowych filozofów”, a „ironia zagląda do kościoła”"57 już nieomal przez wszystkie okna poezję wczesnego Zagajewskiego i jego rówieśników czytać możemy z tą samą co wówczas niepewną siebie wiarą w duchową sprawczość poezji. Mimo że dziś autor Komunikatu myśleć chce o ,istocie poezji” jako o ,śladzie ognia na metalu", powstającym, gdy niefrasobliwe dziecko wkłada łyżeczkę do płomyka

\footnotetext{
53 J. Garlicz, dz. cyt., s. 135.

${ }^{4}$ S. Barańczak, „Powiedz prawdę, do tego stużysz”, „Student” 1972, nr 11, s. 5.

55 Tamże.

56 Tamże.

57 A. Zagajewski, Nowi filozofowie [w:] tegoż, List. Oda do wielości. Poezje, dz. cyt., s. 35.
} 
świecy ${ }^{58}$, być może pół wieku temu widzieć wolałby ją nie tyle w „śladzie ognia”, co raczej w błogosławionej ciekawości dziecka - które „ducha” dostrzega nagle w powstającym za jego sprawą frapującym kształcie, przemieniającym trzymany w ręku pospolity przedmiot w obiekt zadziwienia i czci. Można chyba zaryzykować tezę, że na podobnej zasadzie związek ten oglądać woleliby wszyscy autorzy podchodzący do literatury w sposób, który tu określam mianem postsekularnego. W ich praktyce pisarskiej zawsze jest ona bowiem mniej lub bardziej afirmowana: to wszak literackie mechanizmy i zabiegi, odpowiedzialne za nie całkiem w religijnym dyskursie akceptowalne „zabarwienia” i „przetworzenia”, powołują do życia nowe, frapujące, choć wiekuiście „niedoskonałe”, literackie teologie ${ }^{59}$ - czy może raczej nie całkiem nowe nie całkiem teologie.

Również i użyte w poprzednim zdaniu (nie całkiem może zręczne) zaprzeczone konstrukcje przysłówkowe pochodzą od poety, który wziął udział w ankiecie „Aneksu”. Tym razem jest to jednak Feliks Niedolski - czyli Stanisław Barańczak - a refleksje zaprezentowane w jego eseju o tytule Dlaczego nie catkiem jestem chrześcijaninem $\mathrm{w}$ jeszcze inny sposób artykułują postsekularną ambiwalencję i pograniczność duchowej drogi poetów jego pokolenia. Do głosu dochodzą one już w tytule. $Z$ jednej strony stanowi on wszak krytyczne odniesienie do słynnego, pochodzącego z 1927 roku odczytu Dlaczego nie jestem chrześcijaninem Bertranda Russella. Z drugiej, co wyznaje poeta na wstępie, tekst ów wielokrotnie w PRL-u publikowany - był dla niego ,jedną z ważniejszych lektur wczesnej młodości” ${ }^{60}$, która wespół z postawą rodziców ukształtowała jego, jak przyznaje, „ateistyczny” światopogląd. Poddał go Barańczak krytyce na skutek „najsilniejszego chyba życiowego wstrząsu”, jakim miał okazać się dla niego „marzec 1968”, kiedy to „prawdziwie rozmyślać” zaczął „na temat wiary i religii”"1. Spodziewana wszakże konwersja nie nastąpiła, zaś poeta nie stał się „całkiem chrześcijaninem”, czemu na drodze stanęła nie tyle, jak powie kokieteryjnie, jego „beznadziejna ignorancja w sprawach religii”, ile niemożność udzielenia sobie odpowiedzi na fundamentalne - zwłaszcza zważywszy na czas jego zadania - pytanie: „Czy można sobie wyobrazić religię, która istniałaby bez autorytetu, i człowieka religijnego, który nie miałby choć po części autorytarnego charakteru?”'2. Odpowiadając przecząco, wybierze Barańczak „trzecią drogę", „nie całkiem” drogę, czy raczej: drogę do „nie całkiem” przyjęcia chrześcijaństwa, słowem - drogę „bezreligijnego chrześcijaństwa”. Formułę tę powtórzy Barańczak za Dietrichem Bonhoefferem, który wówczas stanie się dla niego

58 Tenże, Poezja wywiesza biata flage, „Zeszyty Literackie” 2018, nr 2, s. 63.

59 Zob. A. Lipszyc, Czas wiersza. Paul Celan i teologie literackie, Kraków, Budapeszt 2015, s. 8-9. O poetach jako o „niedoskonałych teologach” pisze Zagajewski w dalszej części cytowanego wyżej eseju (zob. A. Zagajewski, Poezja wywiesza..., dz. cyt., s. 67).

${ }^{60}$ F. Niedolski [S. Barańczak], Dlaczego nie catkiem jestem chrzéscijaninem, „Aneks” 1977, nr 13-14, s. 124.

${ }^{61}$ Tamże, s. 126.

${ }^{62}$ Tamże, s. 130-131. 
autorytetem, jednak, co wyraźnie zaznaczy, ,autorytetem racjonalnym: potwierdził bowiem (tak jak i Chrystus zreszta) swoje tezy etyczne świadomie wybranym przez siebie losem" "63. Być może z pewnej perspektywy uznać można tę i inne decyzje poety za „nie całkiem” zrozumiałe, jednak z artystycznego punktu widzenia okazały się one niezwykle produktywne - choć z całą pewnością nie całkiem tak, jak w wypadku autorów podążających głównym duktem.

\section{Aneks. Postsekularyzm wobec tradycji badań nad sacrum}

Tajemnicą poliszynela jest, że, podobnie jak „nie całkiem” religijne wiersze Zagajewskiego, Barańczaka, Kornhausera i innych przedstawicieli Pokolenia 68, starający się udzielić na nie odpowiedzialnej odpowiedzi postsekularyzm „nie całkiem” wpisuje się w tradycje badań nad literackim sacrum, w Polsce zainaugurowane i do dziś kultywowane w Katolickim Uniwersytecie Lubelskim. Nie przez przypadek przedstawiciele i kontynuatorzy szkoły Stefana Sawickiego - wyjąwszy drugorzędne wzmianki ${ }^{64}$ - albo nie piszą o nich wcale, albo interesują się wyłącznie „dojrzałymi” tekstami niegdysiejszych nowofalowców, w których znacznie słabiej słyszalne są postsekularne tony (jest tak na przykład w wypadku tekstów o poezji Zagajewskiego autorstwa Zofii Zarębianki $\left.{ }^{65}\right)$. Badania nad sacrum $w$ literaturze koncentrują się wszakże na tekstach religijnie „ustawionych”, w których poszukiwania duchowe prowadzone są, przynajmniej finalnie, w modelu przyświadczenia (jak w liryce religijnej Jerzego Lieberta, Kazimiery Iłłakowiczówny, Anny Kamieńskiej, Jana Twardowskiego czy Karola Wojtyły), albo w wysoko modernistycznej tradycji pogłębionego, erudycyjnego dialogu z chrześcijańską tradycją teologiczną i religijną

${ }_{63}$ Tamże, s. 132. Swój esej kończy Barańczak apologią właściwego dlań etycznego maksymalizmu: „Argument, który mnie osobiście udowadnia konieczność »chrześcijaństwa bez Boga« jest jeden: tak jest trudniej. Tak jest odpowiedzialniej. W taki sposób mogę miłować bliźniego i zarazem być człowiekiem wolnym” (tamże). Więcej o wpływie Bonhoeffera na Barańczaka i innych autorów jego pokolenia piszę w artykule Efekt Bonhoeffera w poezji polskiej od Barańczaka do Różewicza („Konteksty. Polska Kultura Ludowa” 2018, nr 3, s. 177-184).

${ }^{64}$ Dla przykładu, choć powieść Ciepto, zimno nie wyda się Marii Jasińskiej-Wojtkowskiej wystarczająco interesująca, doceni ona, jej zdaniem, „fascynujące Boże Ciato”, zaliczając opowiadanie Zagajewskiego do „nurtu laickiej religijności” (M. Jasińska-Wojtkowska, Problematyka religijna w prozie polskiej 1975 i 1976 [w:] tejże, Horyzonty literackiego „sacrum”, Lublin 2003, s. 387, 391).

65 Zob. Z. Zarębianka, Wokót, ,Mistyki dla początkujących” Adama Zagajewskiego. Próba lektury [w:] tejże, Tropy „sacrum” w literaturze XX wieku, Bydgoszcz 2001, s. 311-320; taż, Aspekty metafizyczne w emigracyjnej poezji pokolenia „Nowej Fali”. Stanistaw Barańczak. Adam Zagajewski [w:] tejże, Czytanie „sacrum”, Kraków, Rzym 2008, s. 72-82. W tym ostatnim tekście, przeprowadzając analizę porównawczą Pragnienia Zagajewskiego i Widokówki z tego świata Barańczaka, dowodziła badaczka, że „w emigracyjnej fazie twórczości obydwu poetów” nastąpiła „znaczna różnica w stosunku do etapu wcześniejszego, kiedy to sfera pytań metafizyczno-eschatologicznych w ogóle nie manifestowała się w tej poezji” (tamże, s. 82). 
(Cyprian Kamil Norwid, Czesław Miłosz, Stanisław Vincenz, Zbigniew Herbert, Gustaw Herling-Grudziński itd.). Na takim tle wczesna poezja Pokolenia 68 nie może nie jawić się jako rodzaj profanacji ${ }^{66} \mathrm{i}$ - podobnie jak wiersze poetów „bruLionu” - sytuować się na marginesach badawczego zainteresowania ${ }^{67}$. Choć nie stanowi to zarzutu (czy badaczom literatury religijnej zarzucać można, że ważnych dla siebie tekstów poszukają raczej w „Verbum” niż w „Aneksie”?), prowokować może próbę doprecyzowania, jaką pozycję w stosunku do tradycji tej zajmuje - zyskujący sobie powoli osobne miejsce w historii polskiego literaturoznawstwa ${ }^{68}$ - postsekularyzm. W zadaniu tym z pomocą przychodzi mi tytuł pisma, z którego pochodzą cytowane frapujące wypowiedzi Zagajewskiego i Barańczaka - można bowiem powiedzieć, że postsekularyzm stanowi aneks. Nade wszystko jest on aneksem jako dodatek, załącznik, uzupełnienie - pracą powstającą post factum i w większym lub mniejszym stopniu modyfikującą stan wyjściowy. Mógłby być on też jednak aneksem jako przybudówką, budynkiem dołączonym do głównego, reprezentacyjnego domostwa. Jak wiadomo, u zamieszkujących go gospodarzy hałaśliwi i nieokrzesani mieszkańcy aneksu budzą nieraz niechęć - tym większą, jeśli zaczynają po swojemu zabierać się za ich największe świętości. Dwa światy te - nigdy sobie nie przedstawione - mogą wręcz nie utrzymywać ze sobą żadnych kontaktów; do lokatorów budynku głównego mieszkańcy aneksu apelują o akceptację, o milczące przyzwolenie, by mogli oddawać się swojemu majstrowaniu swobodnie - ci zaś wymagają od nich nade wszystko respektowania granic i należytej powagi. W końcu - mógłby być postsekularyzm aneksem w znaczeniu wyodrębnionej części czy wnęki większego pomieszczenia, jak w przypadku aneksu kuchennego. $\mathrm{Z}$ całą pewnością byłoby to znacznie bardziej wymagające - aneks taki trzeba bowiem wydzielić, włożyć w to pracę, poświęcić pewną część miejsca, by stworzyć stałą przestrzeń spotkania i wymiany myśli... Kto wie, być może zatem kuchnia, tradycyjne miejsce nieformalnych spotkań, pojawia się tu nie bez kozery - to wszak w niej płonie ogień, to tam bucha żar. $\mathrm{O}$ tradycji chrześcijańskiej jako o ogniu pisał zaś w „Aneksie” - przyznający po latach,

${ }^{66}$ Charakterystyczne jest na przykład, że w swojej monografii o sacrum w poezji Zagajewskiego odwołująca się do prac Sawickiego Bogusława Bodzioch-Bryła cytuje jedynie dwa utwory z pierwszych tomów poety - Niedzielę Palmowa i Prawdę - określając je przy tym jako teksty operujące „sacrum "sprofanowanym "” i „karykaturalnie przekształconym” (B. Bodzioch-Bryła, Kaptan biblioteki. O poetyckiej i eseistycznej twórczości Adama Zagajewskiego, Kraków 2009, s. 54).

${ }^{67} \mathrm{~W}$ przeglądowym tekście poświęconym poezji pokolenia „bruLionu” podkreśla Zarębianka, że sama „obecność w utworach (...) łatwo rozpoznawalnych sygnałów z kręgu tradycji religijnej” nie oznacza, „iż teksty, w których takie motywy się pojawiają, wpisują się wprost w kategorię tekstów wymiaru sacrum”, jeśli zaś już, to w jej ocenie „tradycyjnie rozumiane sacrum zostało w tej poezji poddane totalnej krytyce (...) w celu proklamacji nowego sacrum na miarę nowej ery i poszukującego samozbawienia człowieka” (Z. Zarębianka, „Sacrum” na cenzurowanym. Nowa metafizyczność na nowe tysiąclecie [w:] tejże, Tropy „sacrum”..., dz. cyt., s. 165, 176).

${ }^{68}$ Zob. na przykład D. Ulicka, Między światami. Rzeczywistość w literaturze - literatura w rzeczywistości - rzeczywistość literatury, „Przestrzenie Teorii” 2017, nr 28, s. 45, 52. 
że „żarliwość religijna” nie była wówczas jego „silną stroną” ${ }^{69}$ - Zagajewski: „Korzystają z tego nie tylko wierzący i "praktykujący». My wszyscy, nawet zdeklarowani ateiści, ogrzewamy się przy tym ogniu. Nawet nie wiedząc o tym"70.

\section{Bibliografia}

Barańczak S., „Powiedz prawde, do tego stużysz”, „Student” 1972, nr 11.

Bodzioch-Bryła B., Kaptan Biblioteki. O poetyckiej i eseistycznej twórczości Adama Zagajewskiego, Kraków 2009.

Bogalecki P., Efekt Bonhoeffera w poezji polskiej od Barañczaka do Różewicza, „Konteksty. Polska Kultura Ludowa” 2018, nr 3.

Bogalecki P., Szcześliwe winy teolingwizmu. Polska poezja po roku 1968 w perspektywie postsekularnej, Kraków 2016.

Chylińska T., Haraschin S., Schäffer B., Przewodnik koncertowy, Kraków 1973.

Czabanowska-Wróbel A., Poszukiwanie blasku. O poezji Adama Zagajewskiego, Kraków 2005.

Draguła A., Co musi zrobić polski Kościót?, „Rzeczpospolita”, 5.09.2018, https:// www.rp.pl/Publicystyka/309059895-Co-musi-zrobic-polski-Kosciol.html, dostęp: 26.09.2018.

Draguła A., Kościót różnych prędkości, „Tygodnik Powszechny” 2018, nr 37.

Draguła A., Polacy wierzacy poganie. Ratzinger czytany po 60 latach, „Więź” 2018, nr 1.

Garlicz J. [Zagajewski A.], W kilku punktach, „Aneks” 1976, nr 12.

Habermas J., Wierzyć i wiedzieć, tłum. M. Łukasiewicz, „Znak” 2002, nr 9.

Jasińska-Wojtkowska M., Problematyka religijna w prozie polskiej 1975 i 1976 [w:] tejże, Horyzonty literackiego „sacrum”, Lublin 2003.

Klejnocki J., Bez utopii? Rzecz o poezji Adama Zagajewskiego, Wałbrzych 2002.

Klejnocki J., Dziesięć powodów, dla których inni polscy poeci nienawidza Adama Zagajewskiego [w:] I cień i światto... O twórczości Adama Zagajewskiego, red. A. Czabanowska-Wróbel, Kraków 2015.

Kołakowski L., Stowo wstępne, „Aneks” 1976, nr 12.

Kornhauser J., Życie wewnętrzne (Adam Zagajewski) [w:] tegoż, Międzyepoka. Szkice o poezji i krytyce, Kraków 1995.

Kornhauser J., Zagajewski A., Wstęp [w:] tychże, Świat nie przedstawiony, Kraków 1974.

Lipszyc A., Czas wiersza. Paul Celan i teologie literackie, Kraków, Budapeszt 2015.

Mc Clure J., Pótwiary. Literatura postsekularna w czasach Pynchona i Morrison, tłum. T. Umerle, Kraków 2016.

Mountford B., Christian Atheist: Belonging Without Believing, Winchester 2011.

${ }^{69}$ A. Zagajewski, W cudzym pięknie, Kraków 2007, s. 120.

${ }^{70}$ J. Garlicz, dz. cyt., s. 137. 
Niedolski F. [Barańczak S.], Dlaczego nie catkiem jestem chrześcijaninem, „Aneks” 1977, nr 13-14.

Nyczek T., Jakiś On [w:] Określona epoka. Nowa Fala 1968-1993, wyb. T. Nyczek, Kraków 1995.

Nyczek T., Kos. O Adamie Zagajewskim, Kraków 2002.

Ratzinger J., Die neuen Heiden und die Kirche, „Hochland” 1958/1959, nr 51.

Taylor Ch., A Secular Age, Cambridge, MA, London 2007.

Ulicka D., Między światami. Rzeczywistość w literaturze - literatura w rzeczywistości-rzeczywistość literatury, „Przestrzenie Teorii” 2017, nr 28.

Zagajewski A., Boże Ciato, „Odra” 1975, nr 3.

Zagajewski A., Budowniczy Peiper [w:] J. Kornhauser, A. Zagajewski, Świat nie przedstawiony, Kraków 1974.

Zagajewski A., Ciepto, zimno, Warszawa 1975.

Zagajewski A., Drugi oddech, Kraków 1978.

Zagajewski A., Komunikat, Kraków 1972.

Zagajewski A., List. Oda do wielości. Poezje, Paryż 1983.

Zagajewski A., Nie oddamy Kornhausera!, „Student” 1972, nr 19.

Zagajewski A., Poezja wywiesza biata flage, „Zeszyty Literackie” 2018, nr 2.

Zagajewski A., „Polska zdziecinniata”. „Żcie utatwione”, nowy świat kultury [w:] J. Kornhauser, A. Zagajewski, Świat nie przedstawiony, Kraków 1974.

Zagajewski A., Sklepy mięsne, Kraków 1975.

Zagajewski A., W cudzym pięknie, Kraków 2007.

Zagajewski A., Walka konkretu z symbolem [w:] J. Kornhauser, A. Zagajewski, Świat nie przedstawiony, Kraków 1974.

Zarębianka Z., Aspekty metafizyczne w emigracyjnej poezji pokolenia „Nowej Fali”. Stanistaw Barańczak. Adam Zagajewski [w:] tejże, Czytanie „sacrum”, Kraków, Rzym 2008.

Zarębianka Z., „Sacrum” na cenzurowanym. Nowa metafizyczność na nowe tysiąclecie [w:] tejże, Tropy „sacrum” w literaturze XX wieku, Bydgoszcz 2001.

Zarębianka Z., Wokót „Mistyki dla początkujących” Adama Zagajewskiego. Próba lektury [w:] tejże, Tropy „sacrum” w literaturze XX wieku, Bydgoszcz 2001. 